1. Вера и жизнь : [двухнедельный журнал Черниговской епархии]. - 1913-1916 гг. 2. Відділ Державного архіву Чернігівської області в м. Ніжині (ВДАЧО в м. Ніжині) Ф. 1353, оп. 1. од. зб. 46. - Отчет за 1913 г по учебной части Мринской Людмилинской женской учительской семинарии, 1913 г. - 587 арк. 3. Державний архів Чернігівської області (ДАЧО у м. Чернігів) Ф. 759, оп. 1, од. зб. 2. - Черниговское одноклассное приходское училище. Классный журнал, 1916-1917 гг. - 62 арк. 4. ДАЧО у м. Чернігів. Ф. 980, оп. 1, 20 од. зб. - Чернігівський учительський інститут, 1916 р. 5. Добровольский П. Летние курсы церковного пения в Чернигове / П. Добровольский // Прибавление к Черниговским епархиальным известиям. - 1897. - № 17. C.620. 6. Отчёт о занятии на временных педагогических курсах для народных учителей и учительниц Новозыбковского уезда Черниговской губернии. [сост. Т. Г. Лубенец]. - К. : Тип. Г. Л. Фронукевича, Никольская улица, 11, 1885. - 64 с. 7. Отчёт Черниговской губернской земской управы за 1898 г. - Чернигов : Тип. губернского земства, 1899. - 319 с. 8. Центральний державний історичний архів України (ЦДІА України у м. Київ) Ф.296, Оп. 296, од. зб. 54. С циркулярами и другими распоряжениями Министерства народного просвещения и г. Попечителя Киевского округа, 1889 г. - 68 арк. 9. ЦДІА України у м. Київ. Ф.707, Оп. 207, од. зб. 87. - Переписка с Министерством народного просвещения дирекции народных училищ Черниговской губернии и Киевского общества грамотности об организации летних курсов церковного пения, 1887 г. 48 арк. 10. ЦДІА України у м. Київ. Ф.707, Оп. 209, од. зб. 17. - Дело Управления Киевского Учебного округа. Об устройстве учительских съездов и педагогических курсов в Черниговской и Полтавской губерниях, 1885 г. - 42 арк. 11. ЦДІА України у м. Київ. Ф.830. Оп.1, од. зб. 1390. Глуховское 3-классное училище Ф. А. Терещенко. Отчеты, 1887 г. - 128 арк. 12. ЦДІА України у м. Київ. Ф 1191, Оп.3, од. зб. 4. - Статистические сведения о Черниговской губернии, 1879 г. 87 арк. 13. ЦДІА України у м. Київ. Ф. 1439. Оп.1, од. зб. 129. - Сведения об училищах г. Чернигова, 1910 г. - 536 арк.

I. М. Мельничук,

доктор педагогічних наук, доцент, Тернопільський державний медичний університет імені I. Я. Горбачевського

\title{
ОНТОЛОГІЯ ІННОВАЦІЙНО-ТЕХНОЛОГІЧНИХ ПРОЦЕСІВ У ВИЩІЙ ШКОЛІ
}

Мельничук І. М. Онтологія інноваційно-технологічних процесів у вищій школі.

У статті розкрито сутність інноваційно-технологічних процесів, які відбуваються у вищій школі на сучасному етапі розвитку освіти. Узагальнено наукові підходи до розуміння категорії «педагогічна технологія». Структуровано три принципово відмінні між собою технологічні схеми організації навчального процесу, які з'являються в науково-педагогічних дослідженнях.

Ключові слова: інновація, педагогічна технологія, інноваційно-технологічні процеси, технологічні схеми організації навчального процесу.

Мельничук И. Н. Онтология инновационно-технологических процессов в высшей школе.

В статье раскрыта сущность инновационно-технологических процессов, которые происходят в высшей школе на современном этапе развития образования. Обобщены научные подходы к пониманию категории «педагогическая технология». Структурированы три принципиально разные технологические схемы организации учебного процесса, которые появляются в научно-педагогических исследованиях.

Ключевые слова: инновация, педагогическая технология, инновационно-технологические процессы, технологические схемы организации учебного процесса.

Melnychuk I. M. Onthology of innovation and technological processes in high school.

The article reveals the essence of innovation and technological processes that take place in high school at the present stage of development of education. Scientific approaches to understanding the category of «educational technology» are generalized. Three fundamentally different technologic systems of the educational process that appear in scientific and educational research nowadays are structured.

Key words: innovation, educational technology, innovation and technological processes, technologic systems of the educational process. 
Історія освіти - це історія творчого пошуку найбільш ефективних систем організації та технологій навчання. Система освіти більшості розвинутих країн світу в останні десятиріччя перейшла на новий щабель, який характеризується такими концептуальними змінами: відношення до тріади «знання, уміння $\mathrm{i}$ навички» як пріоритетної мети освіти замінюється цінностями мислення, творчості, компетентностей особистості, що означає заміну традиційних підходів до змісту освіти компетентнісним підходом; діяльнісний підхід витісняе традиційний предметно-репродуктивний, позаяк освітні цінності і смисли змінюють зміст: не «ви повинні вивчити і відтворити...», а «ми допоможемо вам оволодіти і застосувати...»; у навчальному процесі змінюється характер педагогічних відносин, за яких авторитаризм поступається місцем співробітництву, партнерству в пізнанні та діяльності [7, с. 7].

Аналіз останніх досліджень і публікацій дозволяє дійти висновку, що дослідники і науковці акцентують увагу на високих, інтенсивних, перспективних сучасних педагогічних технологіях $[1 ; 3 ; 4]$ та проблемах педагогічної інноватики [2; 5]. 3 метою визначення загальновизнаних підходів до розуміння педагогічних нововведень науковцями здійснюється термінологічно-класифікаційний аналіз понять «технологія» та «педагогічна інноватика» (Є. Бершадський, Г. Бордовський, В. Лазарев, С. Мамрич, С. Поляков та ін.), аналізуються дидактично-інноваційні аспекти вивчення й застосування педагогічних технологій у вищій школі (І. Дичківська, Т. Дмитренко, А. Нісімчук, О. Падалка, О. Пехота, I. Підласий, Л. Романишина та ін.), визначаються шляхи моделювання педагогічного процесу та проектування інноваційних педагогічних систем у сучасному освітньому просторі.

Невирішеними частинами загальної проблеми залишилися питання стосовно онтології інноваційно-технологічних процесів у вищій школі.

Процес інноваційних змін у педагогіці розпочався в 40-50-х роках минулого століття, але й нині проблема управління інноваційно-технологічними процесами, що використовуються для підготовки фахівців у вищій школі, набуває актуальності. Відбувається перехід системи освіти до якісно нового стану, оскільки інновації в освіті вважаються процесом творення, запровадження та поширення в освітній практиці нових ідей, засобів, педагогічних технологій. Тому педагогічна діяльність викладача вищої школи переживає період активних трансформацій.

Виникає необхідність переосмислення шляхів підготовки фахівців у ВНЗ на основі відмови від усталених традицій і стереотипів. Для цього потрібні прозорі та зрозумілі всім «методології проектування» освіти, а також відповідні їм інноваційні технології підготовки майбутніх фахівців, оскільки нешаблонна творча праця активізує креативні зусилля як викладача, так і студента в пошуках нового, розширює можливості для розвитку розумового, соціального і духовного потенціалу особистості. Для визначення оптимальних інноваційно-технологічних процесів професійної підготовки у ВН3 проведемо термінологічний аналіз таких основних понять, як «інновація» $\mathrm{i}$ «технологія».

Інновації (нововведення) в освіті об'єднують «мету, зміст, методи, прийоми, способи і форми взаємодії педагогів і суб'єктів учіння, методики їхньої поведінки в певних стандартних ситуаціях» [8, с. 268]. Термін «інновація» має комплексне значення, оскільки складається 3 двох форм: власне ідеї та процесу ії практичної реалізації. Тому педагогічну інноватику можна розглядати як сферу науки, що вивчає навчально-виховні процеси, які грунтуються на створенні нової практики освіти.

Формування педагогічних інноваційних процесів відбувається на основі комплексної реалізації загальнонаукових підходів, на основі яких синтезуються нові розробки в галузі наукової організації професійної підготовки майбутніх фахівців. Педагогічна культура, що ввібрала в себе попередні досягнення, починає продукувати оптимальні напрямки виявлення активності суб'єктів освітнього процесу, нові технології навчання, щоб піднятися на вищий щабель розвитку теорії i практики професійної підготовки фахівців. У філософській літературі цей феномен називається «ініціативною 
nрепарацією» (за визначенням Т. Котарбінського). Сутність іiі полягає в тому, що діяльність шляхом систематичного засвоєння вже накопиченого дає переваги перед творчим зусиллям, якщо останнє нехтує ініціативною препарацією. «Вантаж» культурного спадку одночасно ускладнює «оволодіння цілим» - звідси головна вимога прогресу в сучасному суспільстві: звільнятися від елементів культури, які втратили значення, що передбачає заміну деяких традиційних методів навчання (читання лекції в буквальному розуміння слова «лекція» - читання) інноваційними технологіями підготовки фахівців.

Ще одна проблема, що виникає в міру «інноваційного накопичення» - зростання опосередкованих інструментальних дій (сукупності методів i методик у підготовці фахівців), які не дають змоги безпосередньо досягнути сформульованої мети і потребують складного кооперування систем діяльності викладача і студентів в освітньому середовищі, яке все більше розширюється. Відповідно відбувається пошук нових технологій навчально-пізнавальної діяльності майбутніх фахівців і педагогічної роботи викладачів на основі знань нових механізмів структурування цих видів діяльності. Це відбувається для раціоналізації дій в методологічному смислі цього слова.

Термін «технологія» (з грец. techne - майстерність) - один із найбільш популярних у сучасній психолого-педагогічній літературі, що означає педагогічну діяльність, яка максимально реалізує закони навчання, виховання й розвитку особистості та $є$ одним із компонентів педагогічного процесу, які шляхом послідовної реалізації сукупності способів педагогічної взаємодії гарантують розв'язання педагогічних завдань.

Зрозуміло, що окремої конкретизації потребує поняття «педагогічна технологія». Якщо технологічний підхід у виробничій сфері можна визначити за допомогою таких трьох основних характеристик, як концентрований вираз досягнутого рівня розвитку виробництва, упровадження наукових досягнень у практику, показник високого професіоналізму діяльності, то застосування технологічного підходу в освітньому середовищі $є$ відносно новим явищем i потребує ширшого i більш грунтовного тлумачення.

Технологізація освітніх процесів ще $з$ часів Я.-А. Коменського розглядається як важливий засіб упровадження провідних дидактичних принципів і передбачає чітке дотримання змісту й послідовності поширення нововведень. Використання ефективних технологій навчання на сучасному етапі стає пріоритетною потребою на ринку освітньовиховних послуг і визначає напрямки та способи опанування студентами необхідних професійних знань і вмінь. Складовою високого професіоналізму викладача $є$ досконале володіння педагогічними технологіями. Деякі науковці вважають, що в роботі педагога майбутнього технології будуть визначати успіх на 80\%, а індивідуальна майстерність викладача - тільки на 20\% [6, с.13].

У XX столітті тлумачення поняття «педагогічна технологія» еволюціонувало в двох напрямках: 1) розуміння його як методики застосування різноманітних технічних засобів навчання (40-50 роки), що дало поштовх до інтенсивного розвитку й упровадження технічних аудіовізуальних засобів і програмованого навчання (60-ті роки XX ст.); 2) підвищення ефективності організації навчального процесу на основі обгрунтованих філософією та соціологією концепції системного підходу в дослідженні природних, соціальних, а відтак і педагогічних явищ та процесів.

У 70-ті роки XX ст. спостерігається інтеграція цих двох напрямків обгрунтування поняття педагогічної технології, оскільки модернізація навчального обладнання і навчальних предметних середовищ стала необхідною умовою реалізації прогресивних методик і форм навчання. Тому смислове наповнення педагогічної технології на той час розумілося як дослідження і застосування принципів оптимізації навчального процесу на основі новітніх досягнень науки і техніки.

За останні роки тільки в українських і російських публікаціях можна знайти близько 300 різних тлумачень поняття «педагогічна технологія». У зв'язку з цим виникає потреба в конкретизації розуміння цього феномену. 
Аналіз енциклопедичних джерел та педагогічної літератури показує, що в науковому розумінні й уживанні терміна «педагогічна технологія» ще немає єдиного усталеного й загальновизнаного тлумачення. У наукових колах визначаються різні напрямки його характеристики, що їх узагальнив і згрупував у чотири позиції Г. Селевко [7, c. 25-26].

1. Група науковців, до якої належать В. Бухвалов, В. Паламарчук, Б. Лихачов, Н. Крилов, М. Мейєр, Р. де Киффер, С. Смирнов та ін., визначають педагогічні технології як процес застосування організаційно-методичного інструментарію (набір форм, методів, способів, прийомів навчання і виховання), апаратури (ТЗН), навчального обладнання («від крейди і класної дошки» (Р. де Киффер) до «всіх речей, які можна включити в розетку в стіні» (М. Мейєр).

2. Інші автори (В. Беспалько, С. Гібсон, І. Зязюн, А. Кушнір, Б. Скінер, В. Монахов, М. Чошанов, В. Сластьонін, Т. Сакамото та ін.) розглядають педагогічну технологію як процес комунікації (спосіб, модель, техніку виконання навчальних задач), що грунтується на певному алгоритмі, програмі, системі взаємодії учасників педагогічного процесу. Близьким до цієї позиції є розуміння педагогічної технології як мистецтва, майстерності викладання, виховання. Теоретики цього напрямку вважають, що педагогічну технологію слід розглядати як:

- систематичне використання людей, ідей, навчальних матеріалів і обладнання для розв'язання педагогічних проблем (С. Гібсон);

- змістову техніку реалізації навчального процесу (В. Беспалько);

- складову, процесуальну частину дидактичної системи (М. Чошанов);

- наукове проектування і точне відтворення педагогічних дій, які гарантують успіх (В. Сластьонін);

- модель спільної педагогічної діяльності 3 проектування, організації i провадження педагогічного процесу з безумовним забезпеченням комфортних умов для суб'єктів навчального процесу (В. Монахов);

\section{- оптимальний спосіб дій (досягнення цілей) у визначених умовах (А. Кушнір).}

3. Представники третьої наукової позиції (П. Підкасистий, В. Гузєєв, С. Ведемейєр, М. Ераут, Р. Кауфман та ін.) розглядають педагогічну технологію як широку галузь знань, новий напрямок у педагогічні науці, який потребує однозначної детермінації, гарантованих результатів і який є системою, що вміщує вихідні дані та заплановані результати, засоби діагностики навченості учнів або студентів, набір моделей навчання $\mathrm{i}$ критерії відбору найбільш оптимальної 3 них для конкретних умов (В. Гузєєв) та займається конструюванням оптимальних навчальних систем, проектуванням навчальних процесів (П. Підкасистий).

4. Такі науковці, як М. Кларін, В. Давидов, Г. Селевко, П. Мітчел, Д. Фінн, К. Силбер, Р. Томас пропонують розглядати педагогічні (освітні) технології як багатогранний процес:

- системну сукупність i порядок функціонування всіх особистісних, інструментальних і методологічних засобів, що використовуються для досягнення педагогічних цілей (М. Кларін);

- як комплексний, безупинний процес, що охоплює людей, ідеї, засоби і способи організації діяльності з аналізу проблем і планування, сприяє забезпеченню, здійсненню, вирішенню проблем, що відносяться до всіх аспектів засвоєння знань (визначення, прийняте Асоціацією з педагогічних комунікацій і технологій (США) в 1979 році);

- системний метод створення, застосування i визначення всього процесу викладання і засвоєння знань з урахуванням технічних і людських ресурсів та їх взаємодії, що ставить за мету оптимізацію форм освіти (ЮНЕСКО); 
- як систему функціонування всіх компонентів педагогічного процесу, побудовану на науковій основі, запрограмовану в часі і в просторі - таку, що дає намічені результати (Г. Селевко) [7, с. 26].

Різноманітні трактування поняття «педагогічна технологія» свідчать про те, що це якісно новий рівень у розвитку «виробничого апарату» педагогіки, тому іiі можна розглядати як змістове узагальнення, що охоплює смисли всіх наведених вище визначень.

Розкриваючи сутність педагогічної технології, І. Підласий тлумачить іiі як дослідження і застосування принципів оптимізації навчального процесу на основі новітніх досягнень науки і техніки, підкреслюючи, що оптимізація - це «постійно діюча інновація» [6, с. 48]. Тому збагачення навчання новими ідеями, методами, формами, засобами i технологіями доцільно об’єднати загальною назвою: інноващійні прощеси в освіті. Ми погоджуємося 3 думкою І. Підласого, що педагогічна праця у своєму загальному вигляді тільки специфікою відрізняється від інших видів суспільно-корисної праці, а водночас має свій продукт, свої технології та їх ринкову вартість. Розглядаючи економіку освіти ринково спрямованого суспільства, науковці зазначають, що володіння «високими педагогічними технологіями» стає загальною пріоритетною потребою ринку, визначає напрямки опанування професійних умінь, ураховується при оцінках якості й вартості освітньо-виховних послуг. У ринковому світі, де основними цінностями молоді стають кар'єра і добробут, набуває актуальності застосування нових прагматичних педагогічних технологій, що краще пристосовують людину до труднощів буття в складному, перманентно нестабільному світі. Адже для більшості людей знання набувають конкретного прагматичного i продуктивного змісту як джерело прибутку, самовираження, самовдосконалення, особистісного зростання тощо.

Сутність прагматизму (грец. pragma - діло, дія) полягає в тому, що практична цінність знань означає їхню істинність. Це філософське вчення розглядає дію, доцільну діяльність як центральну, визначальну людську сутність. Представниками прагматизму були американські науковці: філософ, логік і математик Ч. Пірс (автор терміна), психолог і філософ В. Джемс, філософ, систематизатор прагматизму Д. Дьюї. Зокрема, на думку Д. Дьюї, прагматизм здійснив переворот у філософській традиції, рівнозначний революції вчення видатного науковця М. Коперніка, переходячи від вивчення проблем самих філософів до осягнення людських проблем.

Цінність мислення, 3 погляду прагматизму, зумовлюється його дієвістю, ефективністю як засобу досягнення успіху, розв'язання життєвих завдань. Відтак зміст знання визначається його практичними наслідками. Філософське розуміння поняття «знання» розкриває його сутність як селективну, упорядковану, отриману певним способом (методом) інформацію, що оформлюється за певними критеріями (нормами), має соціальне значення і визнається як самі знання певними соціальними суб'єктами та суспільством загалом. Одним із типів знань за рівнем його функціонування визначається професійне знання, що є результатом професійної освіти і разом із практичними уміннями та навичками здобувається майбутнім фахівцем у процесі навчання.

Загальновідомо, що освіта є однією $з$ найширших педагогічних категорій, яка має цілісну, поліфункціональну і полісмислову структуру. Однак на сучасному етапі розвитку освіти відбувається суттєва корекція спрямованості навчального процесу від репродуктивного засвоєння певної суми знань, властивої традиційній технології навчання, до підготовки людини інновачійного типу, яку може сформувати лише інноваційна за своєю сутністю освіта. Актуалізується перехід від авторитарної педагогіки до педагогіки толерантності, де формування самодостатньої особистості здійснюється з урахуванням іï природних здібностей і психологічних особливостей.

На основі аналізу різних підходів до тлумачення педагогічних технологій ми пропонуємо розширене й комплексне розуміння цього феномену: педагогічну технологію потрібно розглядати як науково i методично інтегративну, динамічну, відкриту, інноваційно-продуктивну, синергетичну систему, зумовлену часовими і просторово- 
цільовими характеристиками організації та функціонування сукупності компонентів педагогічного процесу. Ця система об'єднує: викладачів з новими ідеями та практичними методиками і техніками оптимізації навчання майбутніх фахівців на основі реалізації моделей спільної міжособистісної взаємодії суб'єктів освітнього процесу; студентів 3 активним професійно-мотиваційним, ініціативно-творчим, самостійно-діяльнісним і практично-самоосвітнім потенціалом; змістове наповнення професійної підготовки студентів у ВНЗ; науково-методологічні, методико-технологічні, організаційно-діяльнісні та інструментальні засоби навчання, що сприяють процесу реалізації оптимальних педагогічних умов підготовки висококваліфікованих, компетентних фахівців. Місце педагогічної технології в освітньому процесі вищої школи можна відобразити в такій структурно-логічній схемі-моделі педагогічного процесу (рис. 1).

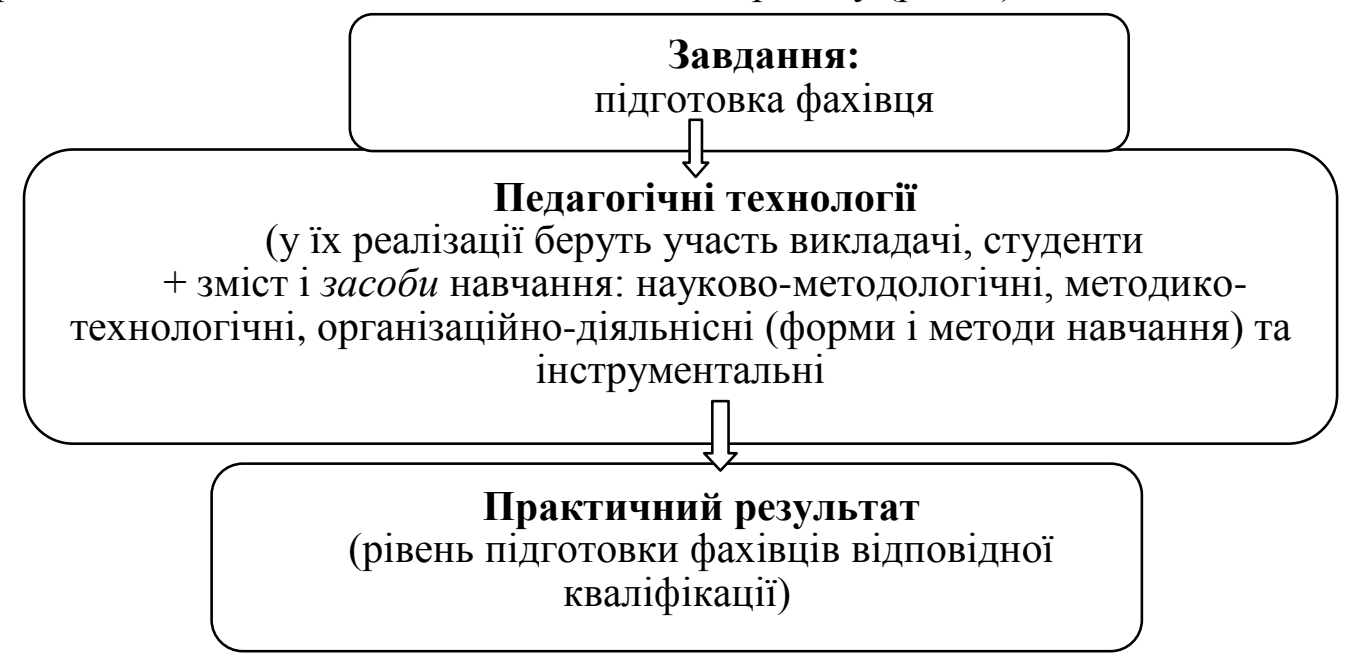

Рис. 1. Структурно-логічна модель педагогічного процесу у ВНЗ

У моделі педагогічного процесу ВНЗ можна визначити основні постійні складники, а саме: викладач, студенти, інформація, що є предметом навчання. Якщо дотримуватися цієї схеми, то за рахунок упровадження нових засобів - того, що служить знаряддям у процесі підготовки фахівців, можна оптимізувати і, можливо, підвищити продуктивність традиційно організованого педагогічного процесу, започаткованого у вищій школі ще в 60-х роках минулого століття (лекційно-практична або лекційно-семінарська система навчання). Оптимізація (лат. optimum - найкраще) в педагогіці розглядається як вид управління педагогічним процесом, що передбачає науково обгрунтований вибір i здійснення найкращого за цих умов змісту і технології навчання 3 позиції критеріїв оптимальності (результативність і якість, витрата часу й зусиль суб'єктами педагогічної взаємодіï), приведення у найповнішу відповідність мети і засобів іiі досягнення.

Змінними компонентами є засоби навчання, якими можуть бути інноваційні методи - способи досягнення цілі, сукупність прийомів й операцій теоретичного та практичного освоєння дійсності, а також людської діяльності, організованої певним чином, і форми проведення занять - способи оптимальної організації та здійснення певних дій. Це передбачає організацію та реалізацію викладачем інноваційнотехнологічного процесу, що уособлює такі компоненти:

- ідею, що істотно змінює організацію навчання;

- детальний опис процесу, всіх його особливостей;

- комплексне застосування засобів навчання;

- досягнення практичного результату, що має бути вищим (або особливим) i встановлюється шляхом діагностики.

Технологія відображає структурно-логічне й алгоритмізоване поєднання різних методик діяльності й передбачає сукупність взаємозумовлених дій i викладача, i студентів. Таким чином, технологія відповідає схемі: «ідея - процес - результат».

У науково-педагогічних дослідженнях з'являються три принципово відмінні між собою технологічні схеми організації навчального процесу: 
1. Продуктивна технологія, або предметно зорієнтоване навчання, коли головною метою є засвоєння навчального матеріалу. Навчання розвивається «від предмета» за схемою: матеріал - студент - результат. Контроль якості засвоєння ігнорує особистість студента і зводиться до контролю засвоєння матеріалу з певної дисципліни. Досягнення запланованих цілей у визначені терміни і на встановленому рівні є основними критеріями навчання. Предметно орієнтоване навчання широко застосовується в навчанні спортсменів, військових, диспетчерів, медиків, де потрібне чітке і глибоке знання предмета. Вимоги надзвичайно високі, а проте цілком ігнорують індивідуальність: той, хто не може в повному обсязі оволодіти програмним матеріалом із певної спеціальності, залишає навчальний заклад. «Предметно орієнтована технологія безжалісна до студентів, але гарантує високий рівень навченості» [6, с. 67].

2. Технологія особистісно зорієнтованого навчання. Показником навчання, спрямованого на створення умов для самореалізації, $є$ прогресивні особистісні зміни розвиненість, незалежність думок, розкріпачення власного Я, самопізнання, самовизначення, самостійність. Цю технологію доцільно використовувати на ранніх етапах соціалізації особистості. Саме в цей період провідним видом діяльності людини стає навчання, формується ії креативний (творчий) потенціал, який є головним засобом розвитку творчості особи.

На Заході тривалий час панівною була якраз технологія особистісно-зорієнтованого навчання, допоки в червні 2002 року німецький уряд не прийняв національний освітній проект «Йдемо на схід», згідно 3 яким «...німецькі педагоги фактично визнали, що тривала орієнтація на розвиток особистості закінчилася повальною малограмотністю» [6, c. 70].

Особливої уваги заслуговує педагогіка співробітництва, що лежить в основі третьої моделі педагогічних технологій.

3. Партнерська технологія (технологія співпраці) передбачає оптимальне поєднання предметно орієнтованого і особистісно зорієнтованого навчання, коли викладач має на меті зреалізувати триєдине завдання: навчати, щоб студенти отримали, зрозуміли i засвоїли максимум конкретних знань і вмінь; розвивати задля утвердження студентами власного Я, особистісних оцінних суджень, створення умов для самореалізації особистості; виховати в майбутніх фахівців особистісно та суспільно важливі якості. Ця технологія найважча для практичної реалізації. Якщо для навчання студентів викладач чітко дотримується програми і вимог до знань, умінь і навичок майбутнього фахівця, то для розвитку і виховання уже фактично дорослих людей необхідно використовувати такі методи, які не завжди можна обмежити певним алгоритмом дій (формулою, правилом, законом). Крім того, для фахівців, віднесених до соціономічного типу професій (учителів, лікарів, соціальних працівників та ін.), міжособистісна взаємодія є основою професійної діяльності. Тому вдосконалення методики підготовки майбутніх фахівців цього профілю грунтується на впровадженні таких форм і методів навчання, що передбачають активну міжособистісну взаємодію, є основою партнерської технології - технології співпраці і водночас визначають сутність інтерактивного навчання.

Педагогічні технології грунтуються на різних формах навчального співробітництва, тому їх уважають інструментарієм досягнення спільної дидактичної мети, одержання запланованого результату, хоча й різними шляхами, методами. У процесі використання педагогічних технологій для підготовки майбутніх фахівців у ВНЗ необхідно враховувати онтологічні засади розуміння цього феномену для оптимізації освітнього середовища у вищій школі. Перспективи подальших розвідок у цьому напрямку ми вбачаємо у науковому обгрунтуванні та методичному забезпеченні оптимальних педагогічних технологій для професійного зростання майбутніх фахівців під час навчання у вищій школі.

\section{Література}

1. Андрущенко В. Високі педагогічні технології / В. Андрущенко, В. Олексенко // Вища освіта України. - 2007. - № 2. - С. 70-76. 2. Богданова І.М. Педагогічна інноватика : [навч. 
посіб.] / І. М. Богданова. - Одеса : ТЕС, 2000. - 148 с. 3. Енциклопедія педагогічних технологій та інновацій / авт.-уклад. Н. П. Наволокова. - Х. : Вид. група «Основа», 2009. - 176 с. - (Серія «Золота педагогічна скарбниця»). 4. Зайчук В. О. Сучасні педагогічні технології: дидактичноінноваційний аспект / В. О. Зайчук, А. С. Нісімчук, Н. В. Тарадюк. - Луцьк : ПВД «Твердиня», 2009. - 312 с. 5. Кларин М. В. Инновации в мировой педагогике: обучение на основе исследования, игры и дискуссии (анализ зарубежного опыта) / М. В. Кларин. - Рига : НПЦ «Эксперимент», 1998. - 180 с. 6. Підласий І. П. Практична педагогіка або три технології: інтерактивний підручник для педагогів ринкової системи освіти / І. П. Підласий. - К. : ВД «Слово», 2004. - 616 с. 7. Селевко Г. К. Энциклопедия образовательных технологий : у 2 т./ Г. К. Селевко. - М. : НИИ школьных технологий, 2006. - Т.18. - 16 с. 8. Ягупов В. В. Педагогіка : [навч. посіб.] / В. В. Ягупов. - К. : Либідь, 2003. - 560 с.

УДК $37.013 .42 \ll 185 / 190 »(477.75)$

E. С. Сімакова, acniрант,

Свпаторійський інститут соиіальних наук РВНЗ «Кримський гуманітарний університет» (м. Ялта)

\section{ЗАГАЛЬНА ХАРАКТЕРИСТИКА СТАНОВЛЕННЯ СОЦАЛЬНОЇ РОБОТИ В КРИМУ (ДРУГА ПОЛОВИНА ХІХ - ПОЧАТОК ХХ СТОЛІТТЯ)}

Сімакова Е.С. Загальна характеристика становлення соціальної роботи в Криму (друга половина XIX - початок XX століття).

У статті проаналізовано стан вивченості проблеми соціальної роботи в Криму в другій половині XIX - початку XX століття та надано іiі загальну характеристику: створення і функціонування соціальних установ. Автор характеризує основні напрямки роботи земств, шкіл, притулків, установ опіки та піклування для неповнолітніх дітей, благодійних установ.

Ключові слова: соціальна робота, неповнолітні діти, соціальні установи в Криму в другій половини XIX - початку XX століття.

Симакова Е. С. Общая характеристика становления социальной работы в Крыму (вторая половина XIX - начало XX века).

В статье анализируется состояние изученности проблемы социальной работы в Крыму во второй половине XIX - начале XX в. и дается ее общая характеристика: создание и функционирование социальных учреждений. Автор описывает основные направления работы земств, школ, приютов, учреждений опеки и попечительства для несовершеннолетних детей, благотворительных учреждений.

Ключевые слова: социальная работа, несовершеннолетние дети, социальные учреждения в Крыму во второй половине XIX - начале XX в.

Simakova E. S. General characteristics of social work in the Crimea (in the second half of the nineteenth - early twentieth century).

The article analyzes the state of knowledge about the problem of social work in Crimea from the second half of XIX century to the early XX century and as well it gives its general characteristics, i.e. the creation and functioning of social institutions. The author describes the main working directions of district councils, schools, orphanages, institutions of guardianship and custody for minor children.

Key words: social work, minor children, social institutions in Crimea from the second half of XIX century to the early XX century.

Розбудовуючи нову систему освіти, маємо насамперед відроджувати національні історико-педагогічні традиції. Для сучасного етапу розвитку української держави характерним $\epsilon$ процес переоцінювання історичного досвіду, в якому $\epsilon$ ще багато недосліджених проблем. Зокрема, до них слід віднести низку питань, пов'язаних зі становленням та розвитком соціальних служб на Україні у часі нашого недалекого минулого. 